\title{
Response to Sam Rosenfeld's review of Party Polarization in America: The War Over Two Social Contracts
}

\author{
B. Dan Wood and Soren Jordan
}

2018

This is the final version as it appears for the citation:

Wood, B. Dan and Soren Jordan. 2018. "Response to Sam Rosenfeld's review of Party Polarization in America: The War Over Two Social Contracts." Perspectives on Politics 16 (3): 798. DOI: $10.1017 / \mathrm{S} 1537592718001962$

The page numbers here are consistent with the published version. Corresponding author: Soren Jordan (sorenjordanpols@gmail.com). 
Response to Sam Rosenfeld's review of Party Polarization in America: The War Over Two Social Contracts

\author{
-B. Dan Wood, Texas A\&M University \\ —Soren Jordan, Auburn University
}

Sam Rosenfeld offers insightful evaluations of our book. He accurately notes that we view party polarization as a discontinuous process, increasing and decreasing through time as a function of elite/mass dissatisfaction (largely economic) and the ability of entrepreneurial elites to mobilize that dissatisfaction. Change in party polarization has always involved partisan warfare over who benefits from government, economic elites or the broader citizenry. Further, contemporary party polarization is not an aberration, but a norm of American politics.

Rosenfeld contrasts our work with that of Hans Noel (Political Ideologies and Political Parties in America, 2013), who studies elite ideologies and their convergence with partisanship. Noel argues that for most of American political history, there was little relationship between elite ideology and partisanship. He finds that by the $1950 \mathrm{~s}$, however the foundations for convergence were in place, marking the potential for contemporary polarization.

As with our work, Noel argues that the impetus for change originated with elites. However, we show that elites were driving partisan behavior as far back as 1794, and during the Progressive Era. We also show that elite ideology for Democrats converged sharply well before 1950, starting with the New Deal. In contrast, postNew Deal Republican ideology was incoherent until the late 1970s. More generally, we argue that the dominant basis for party ideologies through time has been economic, rather than based on the many issues considered by Noel.

Rosenfeld also argues that polarization in previous eras was unlike contemporary polarization. We respectfully disagree. The Founding Era saw vigorous challenges to the Federalist regime, with civil uprisings like the Whiskey Rebellion, and Madison and Jefferson's Democratic-Republican Party sparking Jacobin and Democratic-Republican societies that even physically threatened President Washington and members of his administration. In his farewell address, Washington noted the fragility and instability of the new system due to partisanship (Party Polarization, pp. 39$42)$.

Regarding the Progressive Era, Rosenfeld appropriately notes our discussion and data on civil unrest and violence from the Cleveland through Wilson administrations. However, he then alludes to Cleveland as a Bourbon Democrat, and consensual passage of the Interstate Commerce and Sherman Acts in 1887 and 1890 as countering our argument. However, Cleveland had become more liberal by 1888 , evidenced by his 1888 State of the Union remarks (ibid., pp. 56âĂŞ58). Cleveland supported lower tariffs, increased worker protections, and more vigorous antitrust regulation. By the 1896 election, the two parties had strongly diverged along economic lines, with Democrats subsuming the demands of the Peoples and Free Silver Parties advocating removal from the Gold Standard; lower tariffs; a progressive income tax; nationalization of railroads, telegraphs, and telephones; an eight-hour workday; an end to child labor; and governmental support for unions (pp. 56-58, 69-75). These measures were vigorously opposed by "stand-patter" Republicans.

Finally, Rosenfeld questions our exclusion of the Civil War period from the analysis of party polarization. We state the reason for this exclusion in Chapter 1 (pp. 5-6). To repeat, Party Polarization in America is about party polarization. The Civil War did not involve party polarization, with both Democrats and Whigs supporting and opposing abolition. 